استخلاص الدنا اللاكروموسومي من جراثيم السالمونيلا المعزولة من الحليب الخام خلود خضير نزال

فرع الصحة العامة البيطرية-كلية الطب البيطري- جامعة بغداد- العراق

\title{
الخلاصة
}

جمعت 25 عزلة من عزلات السالمونيلا التي تم عزلها من عينات الحليب الخام والتي جمعت من قرية أبو غريب لغرض دراسة العلاقة بين مقاومتها للمضادات الحيويـة واحتوائها

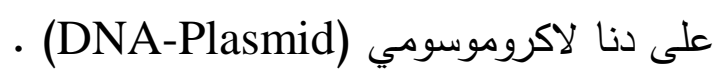
حيث اجريت طريقة التحليل القاعدي ( Alkaline analysis) لتحليل بكتريا السالمونيلا

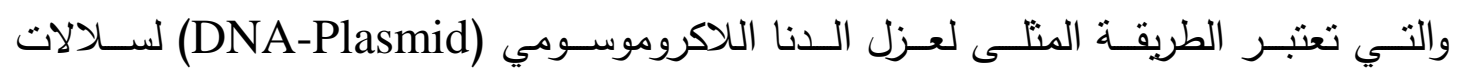

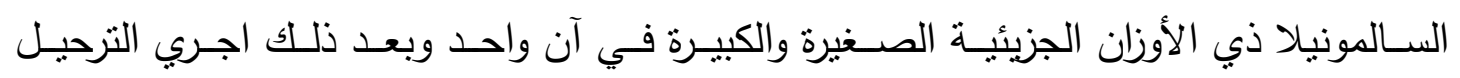

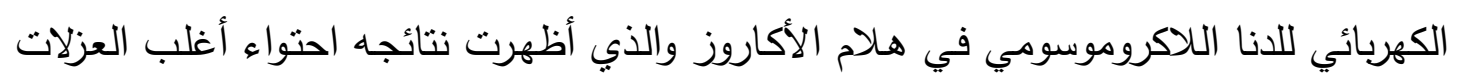
المقاومة لاثثين من المضادات الحيوية أو أكثر على بلازميد كبير منفرد قدر حجمه كيلو قاعدة. 


\section{DNA-Plasmid Extraction Of Salmonella Isolated From Raw Milk}

\section{Khulood K.Nazal}

Dept.of vet. Public Health-College of Vet. Med.-Baghdad UniversityIraq

\section{SUMMARY}

Twenty five Isolates of Salmonella were isolated from raw milk samples which were collected from Abu-Graib village to study the relationship between their resistance to antibiotics and their plasmids contents .

Antibiotic sensitivity test for different antibiotics revealed that most Salmonella isolates were resistant to two antibiotics .

The extraction of the DNA-plasmid revealed that most Salmonella isolates which resistant to two antibiotics or more were contained large, individual plasmids size of (50-70)Kilo Base (KB) while the others isolates were free from such plasmid.

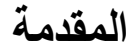

يعد الحليب الخام ومشتقاته من الأغذية المسببة للثورات المرضية بداء السالمونيلا والذي يعتبر

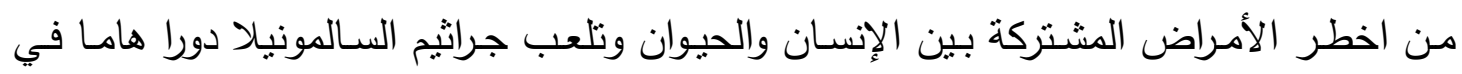

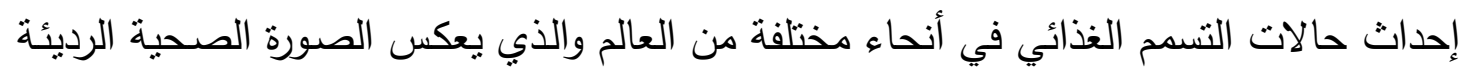

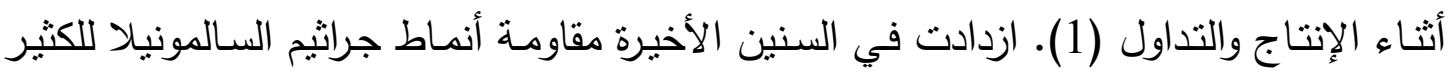

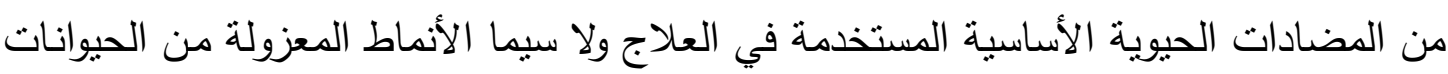

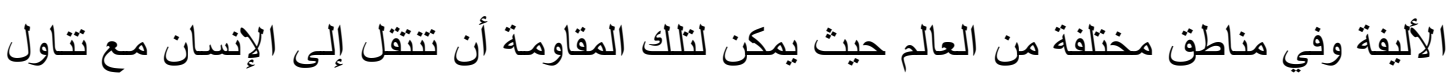

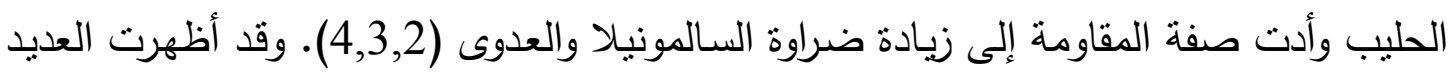

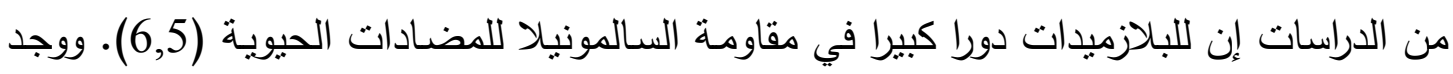

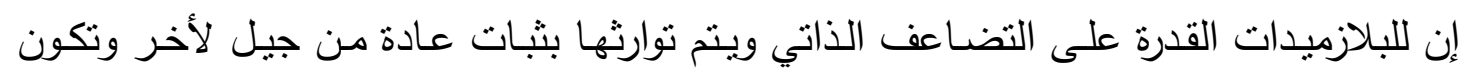

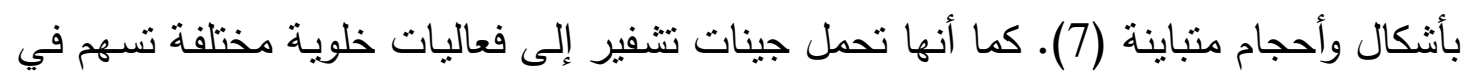

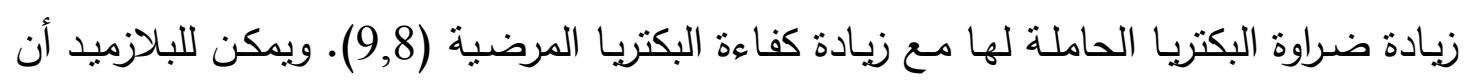

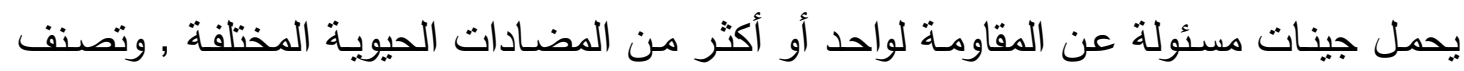
متل هذه البلازميدات على أنها بلازميدات المقاومة (9).

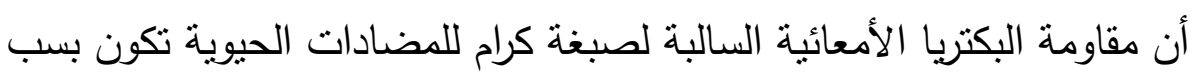


الذي يكون شائع في هذه البكتيريا والذي يحمل جينات تثفير الدقاومة (R-Factor Plasmid)

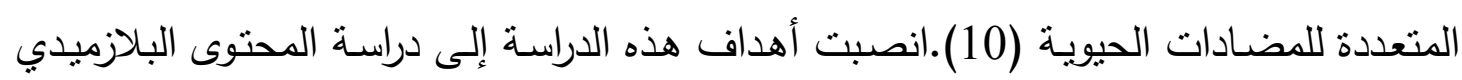
لعزلات السالمونيلا التي أبدت مقاومة لبعض المضادات المضات الحيوية.

\section{المواد وطرائق العمل}

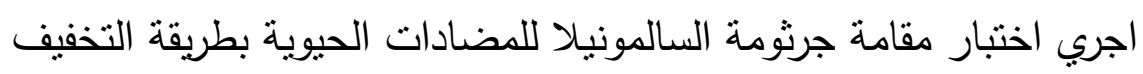

(Agar Dilution Method)ᄋ للعزلات المجموعة اعتمادا على (12).

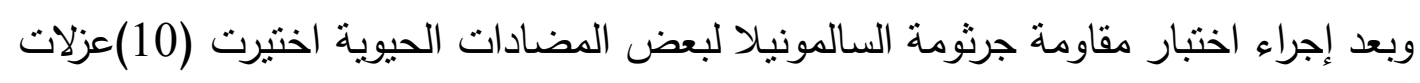

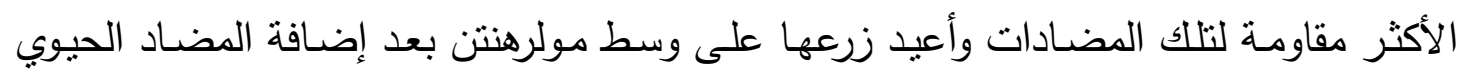
الذي أبدت مقاومتها له وذلك لغرض الأحتفاض بالبلازميد المسئول عن تللك المقاومة وبعدها

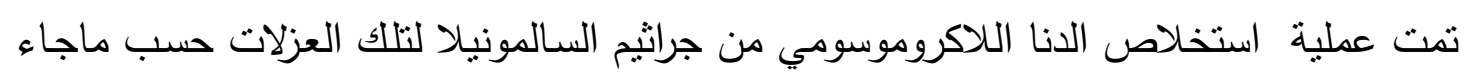
في (12). حيث تعتبر طريقـة التحليـل القاعدي ( Alkaline analysis) لتحليـل بكتريـا

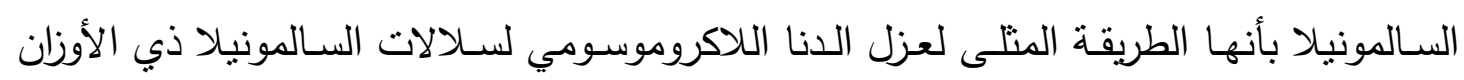
الجزيئية الصغيرة والكبيرة في آن واحد (13). بعد ذللك اجري الترحيل الكهربائي للدنا اللاكروموسومي للعزلات العات العشرة المقاومة في

$$
\text { هلام الأكاروز حسب ماجاء في (12و 14). }
$$

\section{النتائج}

تثير النتائج الموضحة في الجدول (1) إلى نتائج حساسية ومقاومسة عزلات السـالمونيلا

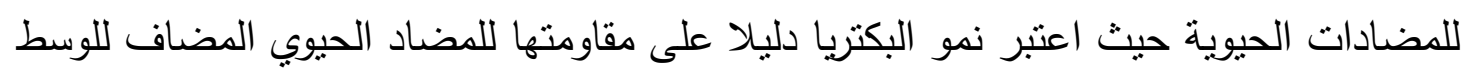

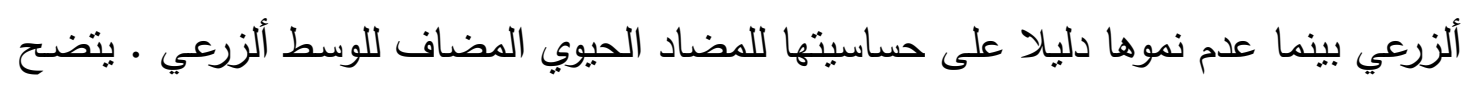

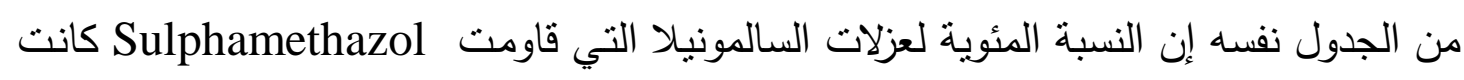

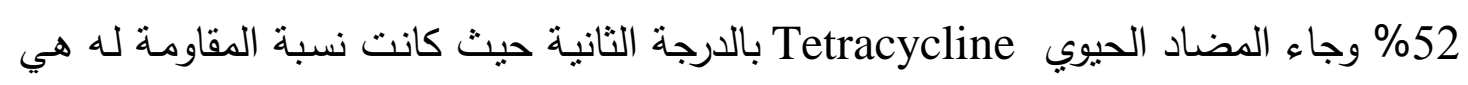

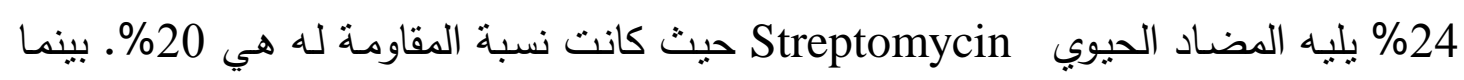
كانت النسبة المئوية لمقاومة المضاد الحيوي Kanamycine هي 4\% وأبدت جميع عزلات

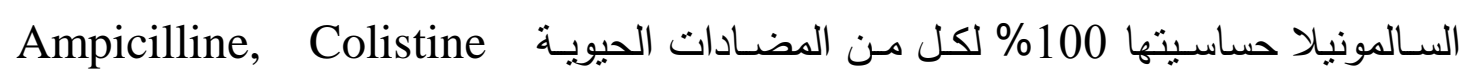

.Chloramphenicol, Carbencilline 
جدول (1): النسبة المئوية لحساسية ومقاومة عزلات السالمونيلا للمضادات الحيوية بطريقة التخفيف

\begin{tabular}{|c|c|c|c|c|c|c|}
\hline النسبة المئوية & عدا العتر & المئوية النسبة & عدد العتر & المفحوصة العتر & رمزه & المضاد الحيوي \\
\hline 0 & 0 & 100 & 25 & 25 & AP & Ampicilline \\
\hline 0 & 0 & 100 & 25 & 25 & $\mathrm{C}$ & Chloramphenicol \\
\hline 0 & 0 & 100 & 25 & 25 & $\mathrm{CL}$ & Colistine \\
\hline 0 & 0 & 100 & 25 & 25 & PY & Carbencillin \\
\hline 4 & 1 & 96 & 24 & 25 & $\mathrm{~K}$ & Kanamycine \\
\hline 20 & 5 & 80 & 20 & 25 & $S$ & Streptomycin \\
\hline 24 & 6 & 76 & 19 & 25 & $\mathrm{~T}$ & Tetracycline \\
\hline 52 & 13 & 48 & 12 & 25 & SM & Sulphamethazol \\
\hline
\end{tabular}

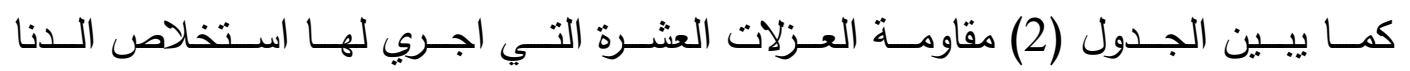

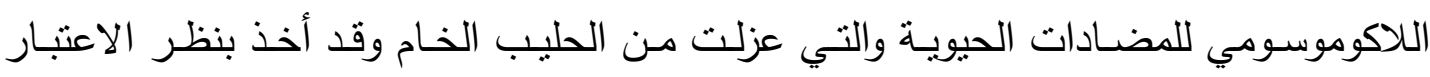

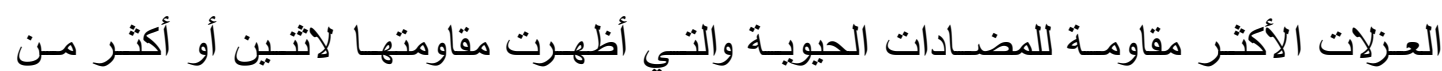

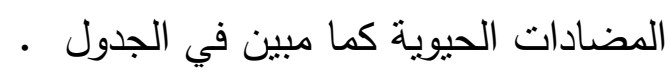

جدول (2) : مقاومة العزلات العشرة التي اجري لها استخلاص الدنا البلازميدي

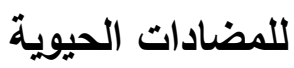

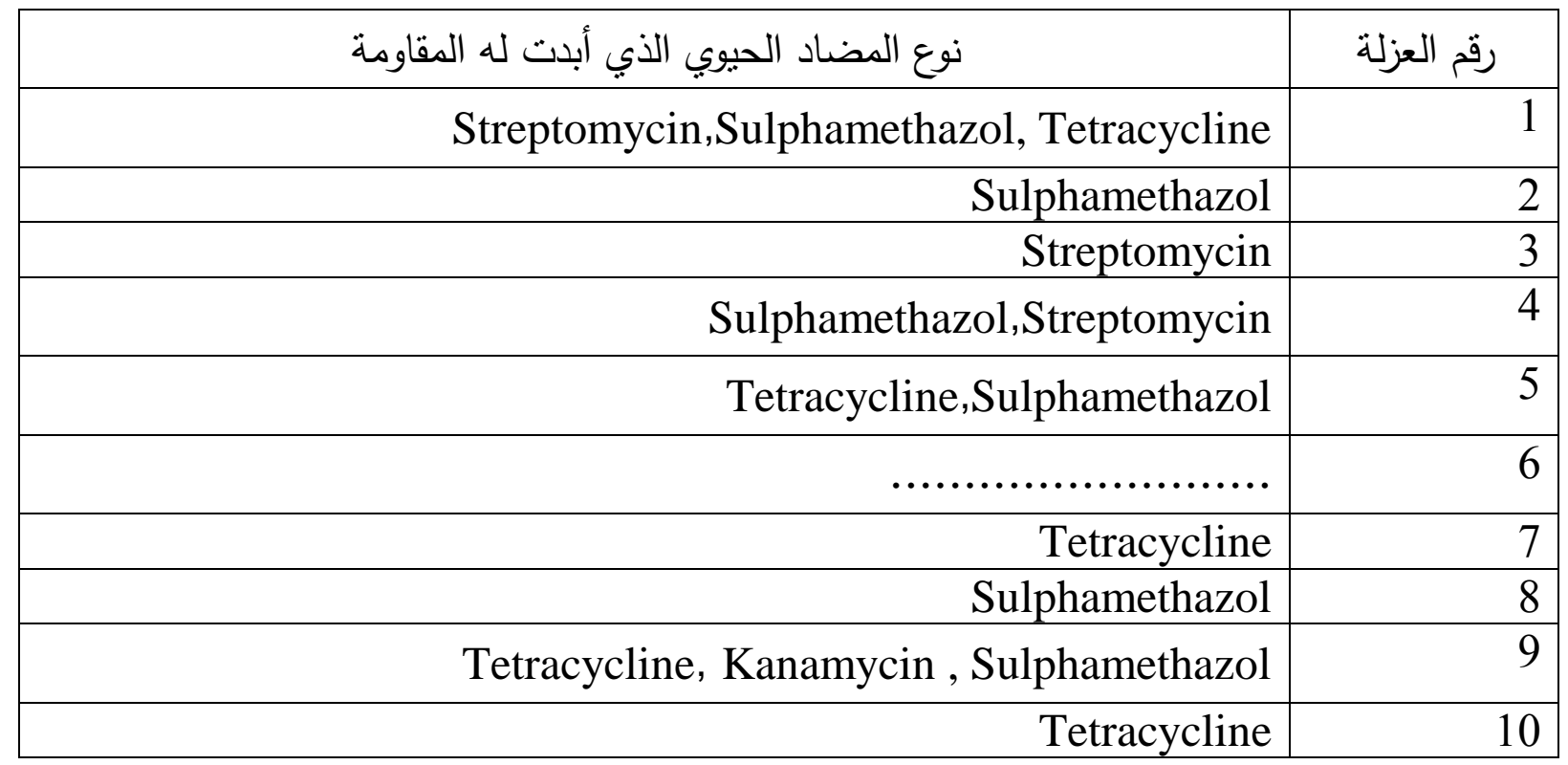


وعند التحري عن المحتوى البلازميدي في هذه العزلات أظهرت احتواء ستة عزلات على بلازميد منفرد كبير قدر حجمـه الجزيئي 50 -70 كيلو قاعدة K.B بإستخدام البلازميدات

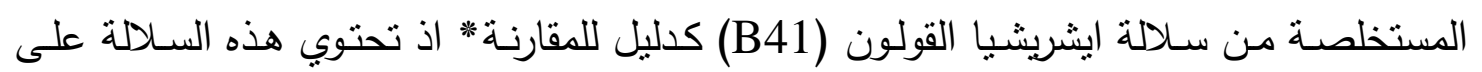

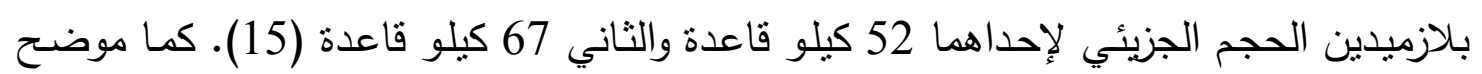
في الثكل (1) • وقد خلت أربع عزلات من هذه العزلات وهي الأكثر حساسية للمضادات الحئ الحيوية

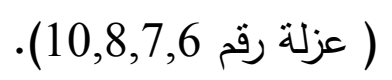

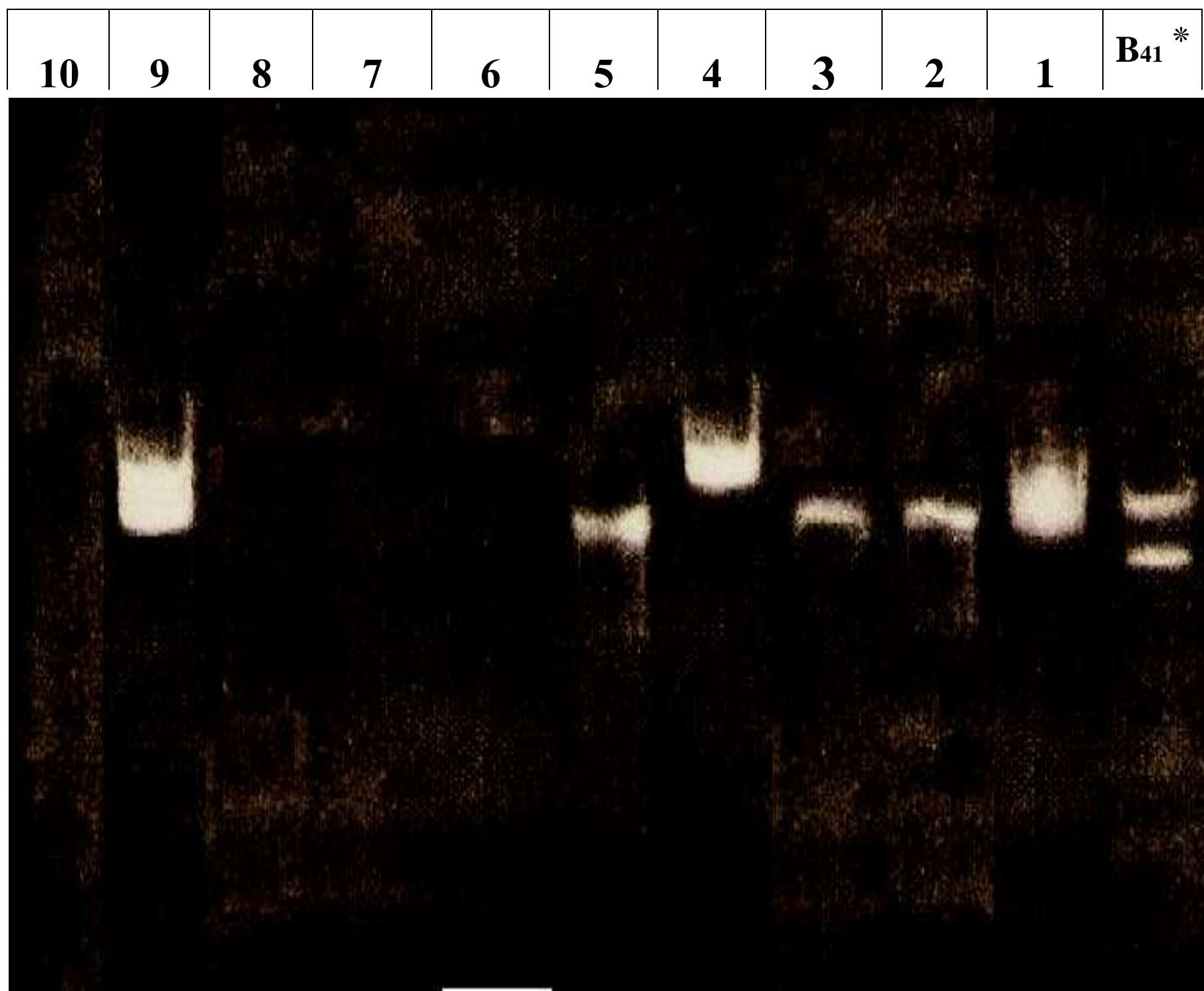

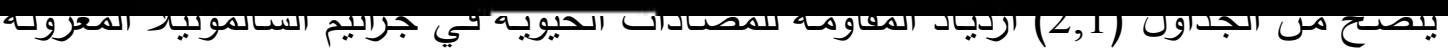
من الحليب الخام وهذا يتفق مع نتائج كل من ( 18,17,16) والذي قد يكون نتيجة الاستخدام

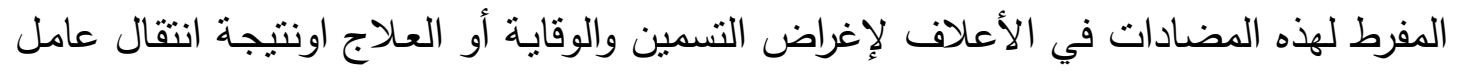

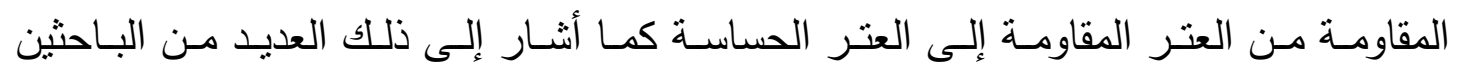


يمكن للبلازميد ان يحمل مورثات تثفر للمقاومة لواحد أو أكثر من المضادات الحيوية المختلفة ويوصف على انـه بلازميد المقاومـة(R-Factor Plasmid) الذي يكون شـائعا في البكتريـا الأمعائية السالبة لصبغة كرام ( 10,9) ـ وقد ازداد الاهنمام العالمي في السنوات الأخيرة بجراثيم

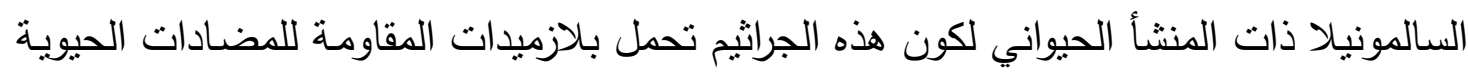
ولكونها المسئولة عن الكثير من الثورات المرضية في الإنسان نتيجة تتاول أغذيـة ذات منشأ حيواني كالحليب ومشتقاته واللحوم (21). المصادر

1.Watson, W.A.(1975).Salmonellosis and meat hygiene -red meat Vet. Rec. 96:374.

2.Anderson, W.H; Wilson, C.R.And Remero (1979). "Relative productivity of five selective plating agars for the recovery of Salmonella from selected food types" .J.Ass-offic. Annual Chain . 62:320-326.

3.Murray, C.J; Reteliff,R.M.Cameron,P.A.And Dixon, S.F.(1986).Drug resistance and anti-microbial agent aus.Vet.J.63(9).286.

4.Centers for Disease Control and prevention (1999). "Salmonellosis" Illinois Morbid Mortal Weekly Rep.12:40.

5.Timoney, F.John (1978). The epidemiology and genetics of antibiotic resistance of Salmonella typhimurium isolated from diseased animals in New York J-infection disease.137 (1):67.

6.Blackburn, B.O.; Schater, L.K. and Sawanson, M.R.(1984). Antibiotic resistance of members of the genus Salmonella isolated from chickens, turkeys, cattle and swine in USA dairy Oct.1981 through Sept.1982 Am.J.Vet.Res.42:1945.

7.Sommers,D.and Sherratt,J.(1986)."Methods in enzymology Ed.M. P. deutscher, 182:317-328.

8. الزعاك : علي عبد الرحمن (1994). البايلوجي الجزيئي لضراوة البكتريا ـ وزارة التعليم العالي -

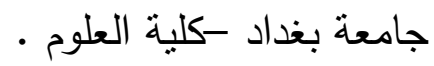

9.Willetts,N.(1985)."Plasmide"Pp.1619.InScaife, J.; Leach, D. and Galizzi, A. (Eds.)."Genetics of bacteria "academic press, London.

10.Quiun, J.; Garter, M.E.; Markey, B. and Garter, G.R. (1998)."Salmonella" Clinical Veterinary Microbiology". 226 -234. 
11.Al-Zaag, A. (1987). "Cloning and molecular characterization of bglucosidase of Citrobacter ferundii" ph.D.Thesis University of Queens Land.

12.Maniatis, T. (1989). "Molecular cloning, Manual cold spring, harbor laboratory " Cold-spring harbor. New York.

13.Aznar, R. ; Amaro, C. and Alcaido, E. (1988). "Characterization of Rplasmids in environmental isolates of Salmonella: Host Rang and Stability" Current Microbial . 17:173-177.

14.Sambrook,J. ; Fritsch, E.F. and Maniatis, T. (1989). "Molecular cloning: a laboratory Manual " Cold- spring Harbor Laboratory, Cold-spring Harbor. New York.

15.Bertin, A. (1985)." F41 ntigen as a virulence Factor in infant mouse of E.coli diarrhea" journal of general Microb. 131:3037-3045.

16.Deanna, A.G. (1999). " Salmonella cereal scare" Information Resource center. [ February 26.12:32].

$$
\begin{aligned}
& \text { 17. الخزعلي: هيفـاء حسين علـي (1990). أنــاط السـالمونيلا المعزولـة مـن الحليب ومشـتقاته }
\end{aligned}
$$

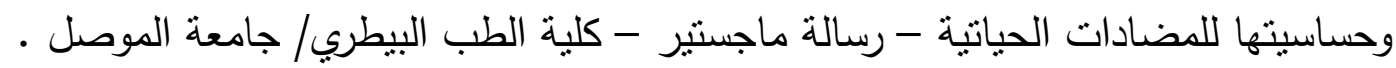

$$
\begin{aligned}
& \text { 18. علي : جليل حسين (1986) ـ تلوث لحوم الأبقار المنتجة في مجزرة الدورة بجراثيم السالمونيلا }
\end{aligned}
$$

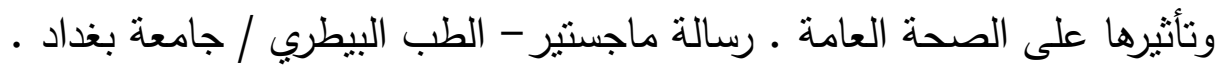

19..Ikeda, Jack, S.; Dawight, C. Hirsh; Speneers, Jang; Event, L.9 Biberstier (1986). Characteristic of Salmonella isolation from animals at a veterinary medical tenching hospital Am.J. Vet. Res.47(2):232.

20.Hadad, J.J and Jemel, A. (1990). Anti-microbial resistance among Salmonella from animals, Vet. Med.-J.Giza.38(1):35-43.

21.Benenson, A.S.(1990).Salmonellosis control Of communicable Disease in man (15 thed) (Pp.381-385) Washington, D.C.: American Public Health Association. 